Sayuti, M., \& Mujiarto. (2018). Employability skills in vocational high school context: An analysis of the KTSP curriculum. Journal of Vocational Education Studies, 1(2), 33-44. DOI: https://doi.org/10.12928/joves.v1i2.707.

\title{
Employability skills in vocational high school context: An analysis of the KTSP curriculum
}

\author{
Muhammad Sayuti ${ }^{*}$, Mujiarto² \\ ${ }_{1}^{1}$ Universitas Ahmad Dahlan, Jl. Pramuka 42, Sidikan, Yogyakarta, Indonesia \\ 2Universitas Muhammadiyah Tasikmalaya, Jl. Tamansari KM 2.5, Tasikmalaya, Indonesia \\ *Corresponding author, e-mail: muhammad.sayuti@mpv.uad.ac.id
}

\begin{abstract}
Employability skills for students are believed to reduce the mismatch between the supply of vocational high school graduates and the demand of job vacancy from industry. For more than three centuries, the gap between the vocational high school and the workplace has become people's concern. It seems that this issue will not end in the near future, rather will be more interesting to be studied because of the complexity of the relationship between the two sectors. The objective of this study, therefore, is to discover of how well employability skills is adopted in the school level curriculum (KTSP) of vocational high schools in Indonesia. To achieve the research's objective, the content analysis to the curriculum was applied. The analysis of KTSP in the subject of entrepreneurship (ENT) and the computer and information management (KKPI) discovers the limited concern and the incomprehensive areas of employability skills adopted. The research findings demand the government to improve the content of employability skills in the curriculum, especially in dealing with the high unemployment rate of vocational high school graduates.
\end{abstract}

Keywords: Curriculum of vocational high school, Employability skills, Indonesia.

\begin{abstract}
Abstrak
Keterampilan kerja bagi siswa diyakini mengurangi ketidakcocokan antara pasokan sekolah kejuruan dan permintaan dari industri. Selama lebih dari tiga abad, kesenjangan antara sekolah kejuruan dan tempat kerja telah menjadi perhatian banyak orang. Tampaknya masalah ini tidak akan berakhir dalam waktu dekat, tetapi akan lebih menarik untuk dipelajari karena kompleksitas hubungan antara kedua sektor. Karena itu, tujuan dari penelitian ini adalah untuk mengetahui seberapa baik keterampilan ketenagakerjaan diadopsi dalam kurikulum tingkat satuan pendidikan (KTSP) SMK di Indonesia. Untuk mencapai tujuan penelitian tersebut, analisis konten terhadap kurikulum diterapkan. Analisis KTSP tentang mata pelajaran kewirausahaan (ENT) dan komputer dan pengolahan informasi (KKPI) menemukan kekhawatiran yang terbatas dan bidang keterampilan ketenagakerjaan yang tidak diadopsi secara komprehensif. Temuan penelitian ini menuntut pemerintah untuk meningkatkan konten keterampilan kerja dalam kurikulum, terutama berkaitan dengan tingkat pengangguran lulusan SMK yang tinggi.
\end{abstract}

Kata Kunci: Employability skills, Kurikulum SMK, Indonesia.

\section{INTRODUCTION}

According to Maclean \& Wilson (2009), the history of study about work can be tracked back about two centuries. For the issue related to employability skills (ES), Cornford (2005) indicates that ES has fueled educational discourse for more than five decades. According to Cornford (2005), Jonathan Payne is one author who has tracked the history of these skills in the context of policy literature. It is revealed that in the UK, generic skills have been fueling the debate on economic competitiveness for 50 years (Payne, 2000). In Canada, on the other hand, generic skills have entered skills development programs since the 1970s (NCVER, 2003). In Australia, generic skills came later (1980s) and the debate about this issue also continues in the educational arena (NCVER, 2003; Cornford, 2005). It seems that the debate around generic skills will not end in the near future. Rather, it will be more intensive in the present situation of economic crisis. Besides, the importance of generic 
skills is not only proved by its long history, but also by the spreading of this issue to many countries. Much literature supports that generic skills have been becoming important on the agenda of many places such as in Australia, in the European countries, in the USA, in Africa and also in the Asia Pacific region (Cornford, 2005; Tilak, 2002; Omar \& Paryono, 2008; Maclean \& Wilson, 2009; ILO, 2008). The two sources of evidence as mentioned before ascertain the existence of employability skills or the similar terms as a global concern.

The issue of employability skills also spreads from the north (the European countries and the North America) to south (Australia and South Africa) and from the developed countries into the developing countries (Maclean \& Wilson, 2009; Omar \& Paryono, 2008; Tilak, 2002). The ES goes around the world with its similarities and differences. The term that is used might be different from one country to another such as generic skills, core competence, basic skills, key qualification and more others. However, the core issue are alike. Moreover, the methods to deliver ES might also different, but their objectives are much the same (Cornford, 2005). It seems that the international community has to deal with a similar challenge.

The global community faces new challenges in the workplace. In many cases, the present situation of the workplace is diametrically different than the past. The rapid development of science and technology, the demographical changes and the newest socio economic trend are the particular factors that drive the new challenges. However, country to county has different ability to deal with the problem. The developed countries apparently have systematically prepared to overcome the problems. In contrary, many developing countries, include Indonesia, are late to handle the problems.

In this era, workplace grows and develops more diverse and complicated. Most of the articles related to employability skills are started with the new features of workplace (Clark, 2007; Cornford, 2005; van Dam, 2004; Brown, Hesketh, \& Williams, 2003). The first feature is the rapid development of science and technology. It creates high-tech jobs that are fully reliant on the newest invention of science and technology (ILO, 2007; Clark, 2007; Brown et al., 2003; Callan, 2003; Payne, 2000). The second feature is the increase of efficiency on resources because of the tighter global competition. The efficiency results reducing human resources and creates substitution from human to machinery. The third feature is the high mobility of workers.

\section{Employability Skills}

Fugate, Kinicki, \& Ashforth (2004) define employability skills as "a form of work specific active adaptability that enables workers to identify and realize career opportunities". Moreover, employability can be characterized as "the relative chances of acquiring and maintaining different kinds of employment" (Brown et al., 2003). Internationally, employability skills have many different names. The variety of the name relies on the countries where the term is used. In Australia, employability skills together with key competencies and generic skills are widely used (Gough, 2009). Callan (2003) reports that the majority of students in Australia more familiar with the term of employability skills (75\%), continued by key competencies (73\%) and core skills (68\%). In the USA, however the popular term is basic skills, necessary skills and workplace knowhow. In the UK, core skills, key skills and common skills are commonly used. Similar to Australia, Canada also uses employability skills (NCVER, 2003). In Indonesia, unlikely, the soft skills are the popular term for employability skills (Wagiran, 2008).

In this literature review, a conceptual comparison of the ES in four countries is made to draw a wider perspective on how employability skills are implemented. In Australia, the

Sayuti, M., \& Mujiarto. (2018). Employability skills in vocational high school context: An analysis of the KTSP curriculum. Journal of Vocational Education Studies, 1(2), 33-44. DOI:

https://doi.org/10.12928/joves.v1i2.707. 
employability skills framework (ESFA) is divided into eight aspects: communication, teamwork, problem solving, self-management, planning and organising, technology, lifelong learning, and initiative and enterprise (Cornford, 2006). The ESFA also includes one group of personal attributes. The personal attributes are include: loyalty, commitment, honesty and integrity, enthusiasm, reliability, initiative and enterprise, self-management, learning, common sense, positive self-esteem, and sense of humour (NCVER, 2003).

In the United Kingdom, employability skills are categorised into two groups (NCVER, 2003), the basic skills and wider key skills. The basic skills consist of communication, numeracy or the application of numbers, and the use of information technology. The wider key skills include working with others, improving own learning and performance and problem solving. In Canada, the ES is grouped into four clusters (NCVER, 2003). The four groups are: fundamental skills; personal management skills; teamwork skills; and an orientation to values and attitude with references to self-esteem, integrity, responsibility. The fundamental skills include: communicate, manage information, use numbers and think/solve problem. The personal management skills consist of five indicators: demonstrate positive attitude and behaviours, be responsible, be adaptable, learn continuously and work safely. The elements of teamwork skills are work with others and participate in projects and tasks.

\section{Employability Skills in Indonesia}

The current study discusses and analyses the curriculum of vocational high school 2006 version which is known as KTSP (school level curriculum). In the 2006 version of the curriculum of vocational high school, the competencies are divided into three main aspects: normative, adaptive, and productive (MOEC, 2007). Normative aspects refer to subjects such as studies if religion, civic education, Bahasa Indonesia, sport, health, art and local culture. Productive subjects focus on technical skills related to the students' interest such as automotive, construction, hospitality, plumbing technology and many others specialisation. Compared to the two previous aspects, the adaptive group is the most similar to the concept of employability skills. Unfortunately, there is a very limited explanation of the philosophical and theoretical bases of this important concept (MOEC, 2007). The soft skills are another term that is used in the daily conversations in Indonesia. However, it is also difficult to find this term in the official education document.

The adaptive subjects in vocational high school comprises of mathematics, physics, chemistry, English, social sciences, computer and organising information skills (KKPI) and entrepreneurship (ENT). Fifty one per cent of the time allocated to learning in vocational schools is spent on adaptive subjects (MONE, 2006). From the list of subjects in the adaptive group, many teachers have commented about the big portion of mathematics, physics and chemistry. They said that these subjects make vocational high school's students more like the general school rather than vocational education (Budiman, 2006). According to the curriculum of vocational high school 2006 version, the objectives of the adaptive subjects are "to educate students to be individual with broad and strong knowledge to adapt with social and workplace changes and to be able to develop themselves in accordance with the development of science, technology and art" (Pusdiknakes, 2006). Moreover, adaptive subjects are also aimed "to be applied in their everyday lives and to underpin their work competences" (Pusdiknakes, 2006). The description about ES brings to the conclusion that adaptive subjects is the most parallel concept of ES. Moreover the entrepreneurship and the computer and organising information skills are the fittest subject to deliver ES in Indonesian vocational school.

Sayuti, M., \& Mujiarto. (2018). Employability skills in vocational high school context: An analysis of the KTSP curriculum. Journal of Vocational Education Studies, 1(2), 33-44. DOI:

https://doi.org/10.12928/joves.v1i2.707. 
Entrepreneurship in vocational high school has special characteristics compared to other subjects. The first characteristic is the fact that entrepreneurship is excluded from the list of subjects in the national exam. The national exam places strong emphasis on the cognitive domain (Candrasari et al., 2008). The second feature of entrepreneurship is the flexibility of the curriculum. This allows teachers to work beyond the curriculum. In turn, this flexibility expands the creativity of the teacher to apply local-based learning. The national curriculum, especially the 1994 version and beyond, values the fact that there is massive diversity in Indonesia, not only in geographical features, but also in social, cultural, religious differences (MOEC, 2007).

\section{Research Questions}

In developing a deeper understanding of employability skills in the curriculum of vocational high school, the current study analyses to what extend is the concept of employability skills and its elements adopted in the KTSP curriculum with regards to the most relevant subjects in vocational high school?

\section{RESEARCH METHOD}

This study applies content analysis to achieve the objectives. In more concise description, Love (2003) adds the purpose of content analysis "is to identify underlying themes, assumptions, beliefs, and the narrative sense-making, and meaning-making structure of the document's author". Many suggest that content analysis is classified into qualitative research (Cohen, Manion, \& Morrison, 2018; Fraenkel \& Wallen, 2006; Lankshear \& Knobel, 2004; Love, 2003). The data for this research are collected from document that related to the research topic. The data that supports this research process, especially when refers to the Love's category is academic and administration. Love (2003) details the academic document such as "faculty handbook, academic calendar, course catalogue, course schedule, faculty vitae, class rosters, program worksheet, administrative forms, application forms, academic procedures manual, accreditation self-study reports, faculty newsletters, and course syllabi".

Lankshear \& Knobel (2004) offer the six steps of content analysis. The process of analysing data is started with organising the text for analysis and determines unit(s) analysis. The second step is read through the texts to be analysed a number of times, marking each and any term related to the analysis. The third step is data coding, in this stage researcher is expected to decide whether textual or contextual meaning will be coded. The fourth step is creating list, categories and other structural forms. The fifth step is to repeat the fourth step until no more categories appear. The last step is interpreting the result. This research applies the first objective of the five aims of content analysis. The main objective is to obtain descriptive information about employability skill in the curriculum of vocational high school in Indonesia. The result, therefore will beneficial to evaluate and to improve the curriculum and at least to address the issue of employability in the context of Indonesia.

The unit analysis of this research is employability skills' element in the school level curriculum which is well known as KTSP imposed since 2006-2013. The content of the 2013 curriculum is not part of the current study (Mulyono \& Munas, 2017; Patwiyanto, Wahyuni, \& Prasetyo, 2018; Setyabudi \& Suranto, 2017). The curriculum here refers to the adaptive subjects group. The normative and the productive subject groups are excluded from the analysis because they are not closely related to the research topic. Moreover, only two from the six subjects in the adaptive group will be analysed (ENT and KKPI). This is because the four subjects are considered as too general and not relevant to the research. The excluded

Sayuti, M., \& Mujiarto. (2018). Employability skills in vocational high school context: An analysis of the KTSP curriculum. Journal of Vocational Education Studies, 1(2), 33-44. DOI:

https://doi.org/10.12928/joves.v1i2.707. 
subjects in the adaptive groups are mathematics, biology, physic and chemistry. The research focus therefore is two subjects that conceptually related to employability skills. They are: entrepreneurship (ENT) and computer and organising information skills (KKPI).

To achieve the research objectives, there are three categories of document available. They are: (1) the policy document, (2) the curriculum, and (3) the syllabus.

\section{The Policy Document}

The policy document here refers to the legal paper published by the Department of National Education to impose the curriculum of vocational high school. The documents consist of two types. First, the decrees and the attachments of the MONE number 22 and 23. The decree number 22 explains the standard of content of the curriculum of primary and secondary schools. The only one page decree declares the minimum content of the curriculum. The attachment however, describes the detail of each subject and each educational level. Furthermore, the decree number 23 describes the standard of competence of primary and secondary school leavers. This document describes the competence in which primary and secondary school leavers have to master. The three groups of competence of vocational high school leavers are placed in this document. The three groups are: normative, adaptive and productive. The short explanation of the groups and the list of the subject in each group also available in this document.

Second, the academic paper of the curriculum of vocational high school. In this document, a brief explanation about the adaptive subjects group is available. The academic paper of the curriculum of vocational high school is published by the Centre of Curriculum Development of the Center of Research and Development of the Department of National Education. The document entitled Naskah Akademik Kajian Kebijakan Kurikulum SMK (the Academic Paper of the Policy Study of the Vocational High School's Curriculum).

\section{The Curriculum}

The curriculum here is the curriculum of vocational high school in which the general description of the objectives, goals and scope of the subjects at vocational high school are listed. The subject groups and the subjects list in the curriculum of vocational high school are the normative, the adaptive, and the productive subject groups. The "normative subjects group" includes (1) Studies of religion (Pendidikan Agama), (2) Civic education (Pendidikan Kewarganegaraan), (3) Indonesian (Bahasa Indonesia), (4) Health and sport (Pendidikan Jasmani Olahraga dan Kesehatan), and (5) Art and local culture (Seni Budaya).

The "adaptive subjects group" includes (1) English (Bahasa Inggris), (2) Mathematics (Matematika), (3) Sciences/biology/physic/chemistry (Ilmu Pengetahuan Alam), (4) Social Sciences (Ilmu Pengetahuan Sosial), (5) Computer and organising information skills (KKPI/Keterampilan Komputer dan Pengelolaan Informasi), and (6) Entrepreneurship (ENT/Kewirausahaan).

The "productive subjects group" includes (1) Basic vocational skills (Dasar Kompetensi Kejuruan) and (2) Vocational competences (Kompetensi Kejuruan).

\section{The Syllabus}

The last document to analyse is syllabuses of two subjects: entrepreneurship (ENT) and computer and organising information skills (KKPI). Since syllabus is decentralised into school level, the syllabus here not come from the Ministry of National Education (MONE, 2006). The syllabus in this research is collected from SMK Negeri 2 Yogyakarta, Indonesia (Heryani, 2009). In reality, the decentralisation of developing syllabus in Indonesia has not

Sayuti, M., \& Mujiarto. (2018). Employability skills in vocational high school context: An analysis of the KTSP curriculum. Journal of Vocational Education Studies, 1(2), 33-44. DOI:

https://doi.org/10.12928/joves.v1i2.707. 
meant that the syllabuses are absolutely different (MONE, 2006). Rather very similar each other because teachers or the teachers forum (MGMP) usually share their syllabus. Besides the syllabus of ENT (Heryani, 2009), the syllabus of KKPI can be seen from the text book of KKPI written by Wijaya \& Mintana (2008).

\section{RESULTS AND DISCUSSION Employability Skills Framework in Australia}

In 1990s the concern of employability skills in Australia has started. The first concept of the ES was the Meyer Key Competencies and the term used was generic skills (NCVER, 2003). The driven factor to raise the concern of ES was the problem of school-to-work transition and the ability of young school leavers to find employment (Cornford, 2006). The Meyer Key Competencies listed six key competencies: collecting, analysing and organising information, communicating ideas and information; planning and organising activities; working with others and in teams; using mathematical ideas and technique; solving problems and using technology (Cornford, 2006). In 2000s the Australian Chamber of Commerce and Industry (ACCI) and the Business Council of Australia (BCA) conducted a study focusing on the employers' view of generic skills. The study result was a new list of the generic skills and the emphasized to the concept of employability skills (NCVER, 2003). The 2002 version of the employability skills is the official document of the ES in Australia. The Employability Skills Framework consists of eight skills groups and one group of personal attribute. The eight skills groups are: communication, teamwork, problem solving, self-management, planning and organising, technology, life-long learning, and initiative and enterprise.

The personal attributes consist of thirteen elements: loyalty, personal presentation, a balanced attitude to work and home life, commitment, common sense, an ability to deal with pressure, honesty and integrity, positive self-esteem, motivation, enthusiasm, a sense of humour, adaptability, and reliability (NCVER, 2003). The three skills groups are new (not available in the Meyer Key Competencies): initiative and enterprise skills, self-management skills and learning skills. The personal attributes is also the extension version of the Mayer Key Competencies.

In Indonesia, in contrary there is no any skills framework as it is available in Australia and other countries. The three ministries that work for interconnected sectors are not bound in the same qualification. The three ministries are the MONE, the Ministry of Industry and Trading (MEMPERINDAG) and the Ministry of Labour and Transmigration (MENAKERTRANS). In regards of the situation, the curriculum in the vocational school is the only instrument to deliver and to measure the skills qualification.

The term of employability skills itself is not available in the official document of vocational school. In the common conversation soft skills is the most used. However, in the official document the term of soft skills is also difficult to find. In Indonesia, the official term of soft skills can be found in the tertiary education level. This is because the Directorate of Higher Education (DIKTI) has a special program to develop soft skills for universities students.

In the KTSP curriculum of vocational high school the competencies of students are divided into three main aspects, the normative, adaptive and productive aspect (MONE, 2006). Normative aspects refer to subjects such as studies of religion, civic education, Bahasa Indonesia, sport, health, art and local culture. Productive subjects focus on technical skills related to the students' interest. Compared to the two previous aspects, the adaptive group is the most similar to the concept of employability skills. Unfortunately, there is not

Sayuti, M., \& Mujiarto. (2018). Employability skills in vocational high school context: An analysis of the KTSP curriculum. Journal of Vocational Education Studies, 1(2), 33-44. DOI:

https://doi.org/10.12928/joves.v1i2.707. 
an official document to explain the philosophical and theoretical bases of this important concept (MONE, 2006).

The adaptive subjects in vocational high school comprises of mathematics, physics, chemistry, English, social sciences, computer and organising information skills and entrepreneurship. Fifty one per cent of the time allocated to learning in vocational schools is for the adaptive subjects (MONE, 2006). From the list of subjects in the adaptive group, many teachers have commented about the big portion of mathematics, physics and chemistry. They said that these subjects make vocational high school's students more like general school (Budiman, 2006). According to the curriculum of vocational high school 2006 version, the objectives of the adaptive subjects are "to educate students to be individual with broad and strong knowledge to adapt with social and workplace changes and to be able to develop themselves in accordance with the development of science, technology and art" (Pusdiknakes, 2006). Moreover, adaptive subjects are also aimed "to be applied in their everyday lives and to underpin their work competences" (Pusdiknakes, 2006).

\section{Employability Skills in the Syllabus of ENT and KKPI}

The following description is the result of the content analysis for the syllabus of ENT and KKPI after they are compared to the employability skills framework Australia. The description is categorised through the skills groups.

The curriculum and the syllabus of ENT and KKPI give a minor attention of the communications skills. The table above only lists one element of ENT that fit to the benchmark: planning for promotion, distribution, pricing and customer services. This fact obviously needs a serious attention, especially in the situation when the current and the future of workplace will be featured by information-based jobs. It is not clear where will the competencies such as listening and understanding; negotiating responsively; empathising; establishing and using networks; and being assertive be delivered.

A minor attention is also given to teamwork skills. From the six elements of teamwork skills in ESFA there are only two similar terms in ENT and KKPI' syllabus. The two terms are working with others and working with peers in which basically the both are the same. However, in regards to the basic culture in Indonesia, working together is part of people life. People in Indonesia hold the values of "gotong-royong" or working together for common goal. The gotong-royong is unpaid work to solve and to develop a common objective. Regardless of the potential, it is the obligation the education sectors to preserve the value "gotong-royong" through a particular form of education and training.

Problem solving that contributes to productive outcomes. The syllabus of ENT gives a better attention (awareness) to the problem solving skills. Quantitatively only three of the seven elements of ESFA appear (exist) in the ENT syllabus. However, the tree factors are the core competences of problem solving skills. The first is creativity and innovation in solving problems and the second is the motivation to participate in overcoming problems. The syllabus also addresses the skills to offer alternative solution. It is obvious that problems might come in a more complex setting, in this situation a comprehensive alternative with a multi-perspectives solution is needed. Accordingly both ESFA and ENT have to develop these important skills in their students' competency. Moreover complicated problems also need team work based solution. For that reason the syllabus pays attention to the ability of students to solve problem in team work bases. Again, this is related to the important issue of specialisation. In the past, multi skilled workers might be easy to find, but in the present time, people skills are tend to be focused for particulars area.

Officially this skills group is the core competencies of ENT in vocational school in Indonesia. This is because the subject title is entrepreneurship. Four out of seven elements

Sayuti, M., \& Mujiarto. (2018). Employability skills in vocational high school context: An analysis of the KTSP curriculum. Journal of Vocational Education Studies, 1(2), 33-44. DOI:

https://doi.org/10.12928/joves.v1i2.707. 
of ESFA are available in ENT syllabus, even with some similarities. It can be found that the parallel terms are creativity, innovative and other abilities related to opportunity. The four skills related to opportunities: to see, to map, to take, to expand opportunities.

Planning and organising that contribute to long term and short-term strategic planning. Seven out of twelve elements of planning and organising skills of ESFA are found in the syllabus of entrepreneurship in vocational high school. The seven elements include: time management, punctual, decision making in a risky environment, identifying the risk of a decision, developing project plan, analysing people and others task, developing vision statement, organising information, and defining business goals; choosing business sector; production plan; marketing plan; financial plan; basic accounting; cost-benefit analysis. Some of the elements of the syllabus of ENT are cognitive-based skills. In contrast almost all the twelve elements of the employability skills framework Australia are in the affective and psychomotor domain. Regardless where the elements of planning and organising are placed in the Bloom taxonomy, the several similarities between ENT and ESFA are a good indicator. As an example the skills related to time management, the ability to develop mission statement and organising information are fundamental skills that students are expected to hold. More importantly these skills will beneficial to prepare them entering a more competitive workplace.

Self-management skills are considered as not important in the syllabus of ENT and KPPI. From five elements of ESFA, there is only one element of self-management in ENT and KPPI. An extra work is needed to track either in what subjects are the elements taken place or is it true that in the whole education system in Indonesia self-management is disregarded. In the curriculum of vocational high school there is one subject names as personal development (MONE, 2006). However, there is no information about what the content and the competency of the subject. According to the decree, the subject of personal development is decentralised to school level (MONE, 2006). The term of personal development also can be found at the standard of the competency of the school leavers especially in mathematics, science and biology (MONE, 2006). It is stated that the school leavers are expected to apply mathematics, science and biology for their personal development. Unfortunately, there is no further explanation about the term.

Learning that contributes to ongoing improvement and expansion in employee and company operations and outcomes. Lifelong learning is an important issue of the more competitive world in the future. Hosseini points out that lifelong learning will be more important because "In the 21st century, workers need to be lifelong learners, adapting continuously to changed opportunities and labour market demands of the knowledge economy education systems in all countries will have to evolve in that direction" (Hosseini, 2006). In contrary, most of the developing countries pay less attention to the importance of long life learning. This research discovers the similar reality. No single factor of lifelong learning skills of ESFA fit to the syllabus of ENT and KKPI. This reality is parallel to the macro condition of education in Indonesia because of the limited access to the higher level of education.

In the KTSP curriculum of vocational high school, technology skills as part of adaptive subject group can be found in KKPI. In contrary entrepreneurship has not any element related to technology skills. By the rule, KKPI is aimed to develop computer skills and other related skills to computer. From the five standard competences and the sixteen basic competences the majority of the competences are related to hard skills related to working with computer. In comparison to the ESFA, two elements of KKPI that fit are working with web-browser and email client software and skill related to data entry.

Sayuti, M., \& Mujiarto. (2018). Employability skills in vocational high school context: An analysis of the KTSP curriculum. Journal of Vocational Education Studies, 1(2), 33-44. DOI:

https://doi.org/10.12928/joves.v1i2.707. 
In the syllabus of ENT and KKPI the word that delivers cognitive skills is prevailing. The term as defining, explaining, describing, identifying are found many times in the syllabus. In contrary, in ESFA words related to cognitive skills are fewer. This fact is one example of the bigger problem of education in Indonesia. Many commentators say that curriculum in Indonesian education system pay more attention to cognitive domain. Students therefore more play a role as "hard disc" to memorise many knowledge rather than to build affective and psychomotor skills.

From the thirteen elements of personal attribute in ESFA only two factors found in ENT and KKPI. The two factors are commitment and motivation. The rest attributes such as ability to deal with pressure, adaptability, enthusiasm, honesty and integrity, loyalty, positive self-esteem, reliability and sense of humour are not include in the two subjects of the adaptive group. It is difficult to assume that the important attributes will be officially delivered from mathematics, biology, chemist and physics.

\section{The content (entrepreneurship)}

The data confirms that the element of employability skills can be found in the entrepreneurship subject. In the 2006 version of the curriculum of vocational high school only $29 \%$ of the syllabus of ENT and KKPI correspond to the ESFA. This is equal to 22 out of 76 elements of the employability skills framework in Australia (ESFA) are associated with the syllabus of entrepreneurship (ENT) and computer and organising information skills (KKPI) in the curriculum of vocational high school in Indonesia. In comparison to the 2004 version, the former curriculum of ENT represents much more than the curriculum of ENT 2006. In the 2004 version, nine of the twenty modules in ENT related to employability skills element in Australian context. The detail of the nine elements is as follows: (1) Building partnership (kiat membangun kerjasama); (2) The art of decision making (kiat mengambil keputusan); (3) Risk taking and be a responsible person (kiat mengambil risiko dan tanggung jawab); (4) Developing idea and opportunity (kiat mengembangkan ide dan meraih peluang); (5) Developing achievement orientation (kiat mengembangkan sikap dan prilaku kerja prestatif); (6) Honesty and discipline (kiat mengembangkan sikap jujur dan disiplin); (7) Creativity and innovative (kiat mengembangkan sikap kreatif dan inovatif); (8) Be independent (kiat mengembangkan sikap mandiri); and (9) Developing communication skills (mengembangkan kemampuan berkomunikasi).

In Indonesia, entrepreneurship is a potential sector, since, workplace sectors are dominated by self-employment. According to Lewwe (2002), about $66 \%$ of workers in Indonesia are self-employed. This proportion is higher than in Bangladesh $(62 \%)$ and Mexico (45\%). This proportion also higher that in the developed countries, $12 \%$. On the contrary, there is a trend that suggests improved education levels will be followed by a decline of interest in self-employment. The data from Statistic of Indonesia as cited by MONE (2007) details that primary school leavers who work as wage earners is $28.59 \%$, followed by junior secondary $39.2 \%$, senior secondary $60.87 \%$ and tertiary education $83.18 \%$. Self-employment is in the opposite direction, start from $71.41 \%, 60.8 \%, 39.13 \%$ and $16.82 \%$ respectively.

Dealing with the gap between the high percentage of self-employed and the low interest to be an entrepreneur, the Indonesian government has been imposing an entrepreneurship subject in secondary and tertiary education. A similar action is also reported in other countries such as in Australia, Europe and America (Thompson, 2006). The Indonesian government's effort is aimed to attract school and university leavers to create new businesses or to open new work places (MONE, 2007). Likewise, to keep pace with the market's need, the Directorate of Vocational Education has a target that $20 \%$ of

Sayuti, M., \& Mujiarto. (2018). Employability skills in vocational high school context: An analysis of the KTSP curriculum. Journal of Vocational Education Studies, 1(2), 33-44. DOI:

https://doi.org/10.12928/joves.v1i2.707. 
vocational high school graduates, will start a new business after finishing their study (MONE, 2007).

This research has several limitations: First, research is purely document-based research accordingly the real situation of the implementation of the KTSP curriculum and syllabus is unknown. Also, how well do the teachers deliver the subjects is unidentified. In Indonesia, where the quality of the education system and resources are far from the benchmark country, the disparity between curriculum, syllabus and the reality might be more apparent. For that reason, a combination between document-based research and survey research will be the best technique to consider in the future research. Second, future studies need comparative analyses of the two curriculums (the KTSP and the 2013 curriculum) as some vocational high schools are allowed to implement "the old" and "the new" curriculum. Third, research limitation is the problem of inter-contextual of language. Language can not only be understood as word and its literal meaning. However, language also brings its context and socio-cultural aspect. The employability skills framework Australia works in their socio economic and cultural circumstances, and might be less relevant for in Indonesian environment. Thus, a crosscheck process to the stakeholders in regard of the substantial meaning of each element of employability skills is needed. The similar process is also needed in analysing of the adaptive curriculum and syllabus of the vocational high school. Fourth, future study need to analyse more subjects outside of the two in the current study, that may relevant in instilling values related to employability skills.

\section{CONCLUSION}

In Indonesian vocational school, the adaptive subjects group is the term to characterise employability skills. There is a different term used to convey employability skills in vocational high school. In the daily conversation, soft skills are the prevalent term for employability skills. However, in the official document adaptive subjects group is the closest word to employability skills.

Twenty-two out of 76 elements of the employability skills framework in Australia (ESFA) are associated with the syllabus of entrepreneurship (ENT) and computer and organising information skills (KKPI) in the curriculum of vocational high school in Indonesia. The twenty nine per cent correspondence of the syllabus to the benchmark framework can be considered as low. This finding supports to the fact that officially the Indonesia government pays a minor attention to the importance of employability skills. No association is found in the skills related to lifelong learning. The ENT and KKPI syllabus have not any element related to lifelong learning.

The highest association between the ESF Australia and the syllabus of ENT and KKPI is found in the two skills group: planning and organising skills and entrepreneurship. The first skills groups associated with about 58\% (seven out of twelve) of vocational high school's syllabus and the second skills group correspond about $57 \%$ (four out of seven) of the ESF Australia.

A better concern and educational policy are needed to solve the disparity between the employability skills framework and the adaptive subject groups in the curriculum of vocational high school. This demand is obviously important because Indonesia is still struggling to reduce the high unemployment rate of the graduates of vocational high school.

\section{REFERENCES}

Brown, P., Hesketh, A., \& Williams, S. (2003). Employability in a knowledge-driven economy. Journal of Education and Work, 16(2), 107-126.

Sayuti, M., \& Mujiarto. (2018). Employability skills in vocational high school context: An analysis of the KTSP curriculum. Journal of Vocational Education Studies, 1(2), 33-44. DOI:

https://doi.org/10.12928/joves.v1i2.707. 
Budiman, A. R. (2006). Hasil Workshop KTSP SMK-SK KKPI versi BSNP. Message posted to DIKMENJUR electronic mailing list, archived at dikmenjur@yahoogroups.com.

Callan, V. J. (2003). Generic Skills Understanding Vocational Education and Training Teacher and Student Attitudes. Adelaide: NCVER.

Candrasari, A., Yunengsih, Y., Widiatmika, I. M. A. A., \& Yuliana, M. (2008). Ujian Nasional: Dapatkah Menjadi Tolok Ukur Standar Nasional Pendidikan? Jakarta: Putera Sampoerna Foundation.

Clark, M. (2007). Understanding and managing employability in changing career contexts. Journal of European Industrial Training, 32(4), 258-284.

Cohen, L., Manion, L., \& Morrison, K. (2018). Research methods in education (8th ed.). London: Routledge.

Cornford, I. R. (2005). Challenging Current Policies and Policy Makers' Thinking on Generic Skills. Journal of Vocational Education and Training, 57(1), 25-46.

Cornford, I. R. (2006). Making Generic Skills More Than a Mantra in Vocational Education Policy. Australian Association for Research in Education Conference. Adelaide: AARE.

MONE. (2007). Rencana strategis Departemen Pendidikan Nasional 2005-2009. Jakarta: Pusat Informasi dan Humas Depdiknas.

Fraenkel, J. R., \& Wallen, N. E. (2006). How to Design and Evaluate Research in Education, Sixth Edition. New York: McGraw-Hill Higher Education.

Fugate, M., Kinicki, A. J., \& Ashforth, B. E. (2004). Employability: A psycho-social construct, its dimensions, and applications. Journal of Vocational Behavior, 65(1), 14-38.

Gough, A. (2009). Pathways and transitions from school to work: Australian experiences. In R. Maclean \& D. N. Wilson (Eds.), International Handbook of Education for the Changing World of Work: Bridging Academic and Vocational Learning (pp. 2263-2278). Dordrecht: Springer.

Heryani, D. R. (2009). Rencana Pelaksanaan Pembelajaran Mata Pelajaran Kewirausahaan. Yogyakarta: SMK N 2 Yogyakarta.

Hosseini, N. D. (2006). Lifelong Learning and the Knowledge Society: Challenges for Developing Countries. Journal of College Teaching \& Learning, 3(12).

ILO. (2007). Skills Development Policies and International Cooperation in East and SouthEast Asia. Debates in Skill Development, Paper 11. Hong Kong: Working Group for International Cooperation in Skills Development (International Labour Office).

ILO. (2008). Skills for Improved Productivity, Employment Growth, and Development. Report $V$ on International Labour Conference, 97th Session. Geneva: International Labour Office).

MOEC. (2007). Naskah Akademik Kajian Kebijakan Kurikulum SMK. Jakarta: Center of Curriculum, Indonesian Ministry of Education and Culture.

Lankshear, C., \& Knobel, M. (2004). A Handbook for Teacher Research: from Design to Implementation. London: Open University Press.

Lewwe, P. G. (2002). Schools and Skills in Developing Countries: Education Policies Socioeconomic Outcomes. Journal of Economic Literature, 40, 436-482.

Love, P. (2003). Document Analysis. In F. K. Stage \& K. Manning (Eds.), Research in the College Context. New York: Brunner-Routledge.

Sayuti, M., \& Mujiarto. (2018). Employability skills in vocational high school context: An analysis of the KTSP curriculum. Journal of Vocational Education Studies, 1(2), 33-44. DOI:

https://doi.org/10.12928/joves.v1i2.707. 
Maclean, R., \& Wilson, D. (2009). Education for the Changing World of Work: Bridging Academic and Vocational Learning, In R. Maclean \& D. Wilson (Eds.), International Handbook of Education for the Changing World of Work. Dordrecht: Springer.

MONE. (2006). Peraturan Menteri Pendidikan Nasional nomor 23 tahun 2006 tanggal 23 Mei 2006 tentang Standar Kompetensi Lulusan untuk Satuan Pendidikan Dasar dan Menengah. Jakarta: Indonesian Ministry of National Education.

Mulyono, A., \& Munas, R. (2017). Produk Kreatif dan Kewirausahaan: Perbankan dan Keuangan Mikro. Yogyakarta: Penerbit Andi.

NCVER. (2003). Defining Generic Skills. Adelaide: National Centre for Vocational Education Research.

Omar, M. S. H., \& Paryono, P. (2008). Current Trends and Issues in VTET: SEAMEO VOCTECH's Response. Bandar Seri Begawan: SEAMEO VOCTECH.

Patwiyanto, Wahyuni, S., \& Prasetyo, S. A. (2018). Produk Kreatif dan Kewirausahaan: Program Keahlian Teknik Komputer dan Jaringan. Yogyakarta: Penerbit Andi.

Payne, J. (2000). The Unbearable Lightness of Skill: The Changing Meaning of Skill in UK Policy Discourse and Some Implications for Education and Training. Journal of Educational Policy, 15(3), 353-369.

Pusdiknakes. (2006). Kurikulum SMK Edisi 2006. Jakarta: Pusat Pendidikan Tenaga Kesehatan.

Setyabudi, D., \& Suranto, S. (2017). Produk Kreatif dan Kewirausahaan: Kompetensi Keahlian Bisnis Daring dan Pemasaran. Yogyakarta: Penerbit Andi.

Thompson, A. (2006). Entrepreneurship and Business Innovation. Dissertation. Perth: Murdoch University.

Tilak, J. B. G. (2003). Vocational Education and Training in Asia, In J. P. Keeves \& R. Watanabe (Eds.), The Handbook on Education Research in the Asia Pacific region (pp. 673-686). Dordrecht: Kluwer Academic Publishers.

van Dam, K. (2004). Antecedents and Consequences of Employability Orientation. European Journal of Work and Organizational Psychology, 13(1), 29-51.

Wagiran, W. (2008). The Importance of Developing Soft Skills in Preparing Vocational High School Graduates. Yogyakarta: Universitas Negeri Yogyakarta.

Wijaya, T. A., \& Mintana, A. (2008). Keterampilan Komputer dan Pengelolaan Informasi untuk SMK and MAK Kelas XII. Jakarta: Erlangga.

Sayuti, M., \& Mujiarto. (2018). Employability skills in vocational high school context: An analysis of the KTSP curriculum. Journal of Vocational Education Studies, 1(2), 33-44. DOI:

https://doi.org/10.12928/joves.v1i2.707. 